\title{
Typology and Activities of Vote Broker In Legislative Election in Bengkulu Province
}

\author{
Wahyu Widiastuti \\ \{w.widiastuti@unib.ac.id\} \\ Department Of Communication Science, University Of Bengkulu
}

\begin{abstract}
The Legislative General Election System with the Most Open Candidate and Voting List System has led to tighter competition among candidates. This competition occurs not only between candidates from different parties in a particular electoral district; but also competition between candidates in the same party. This phenomenon causes all candidates for the legislature to compete to get as many votes as possible. In order to reach out to voters, candidates need intermediaries to introduce themselves. On the other hand, voters as the owner of voting right also need media to get information and get to know more about the legislative candidates they will vote in the voting later. The atmosphere of the political system like this causes opportunities for brokers to emerge. The vote brokers are intermediaries between the candidates and voters. This article will discuss six types of vote brokers and their activities as intermediaries for candidates with voters in the period leading up to the general election.
\end{abstract}

Keyword: Legislative candidate, broker, voters, vote engine

\section{Introduction}

Indonesia has carried out 12 legislative elections from 1955 to 2019. In the twelfth implementation of the election the system used was a proportional election system. The proportional election system means paying attention to the proportion between the number of seats and the number of voters in an area. The proportional system used in the election has changed several times. If the previous elections the system used were proportionally closed, since 2004 the implementation of legislative elections used an open proportional system. In a closed proportional system, voters only choose one picture of the party participating in the election; while in the open proportional system, voters can directly choose the names of candidates for legislative candidates.

The open proportional system that was reused underwent changes in 2009. The legislative elections held in 2009 differed from the previous five years. If the 2004 election used an open system serial number, the 2009 election used a pure open system or the most votes. An open proportional system based on the serial number gives a greater electoral advantage to the legislative candidates with serial number one. In this system, party machines will work more to get votes. While the majority of voters open the system, the serial number of candidates does not become important because those who can reap the most votes have the opportunity to sit in the legislative seat. 
The implementation of the legislative electoral system with a candidate list system that has the most votes, causing each candidate or legislative candidate to face two types of competition, namely: (1) competition for seats between parties where candidates compete for as many seats as possible for their party in each region election; and (2) internal competition within the party, where candidates within the same party and electoral district compete to get the most votes in order to get the opportunity to first occupy the seats obtained by their parties. This phenomenon causes candidates to have a high level of importance with voters in their constituencies. On the other hand, voters also need to know about the conditions and commitments of candidates they will choose against their interests. Therefore voters also need information and interaction with the candidates who contest. Candidates need intermediaries to introduce themselves to potential voters, and vice versa the voters also need a means or channel to be able to explore and obtain information about the candidates they will elect at the time of voting at the polling station (PS).

Substantially, this situation illustrates the existence of a mechanism for information needs that involves three parties, namely: candidates, voters and intermediaries. Although in the electoral administration system there is a campaign mechanism that relies on Campaign Props (CPs) such as posters, leaflets, billboards, banners, and social media, but the needs of information that lead to decisions in choosing from many alternative choices require an interactive communication atmosphere that can socially build mutual trust between candidates and voters. This social role to build mutual-trust is played by vote brokers.

Vote brokers according to [1] are local intermediaries who provide benefits and solve problems for their followers. Instead, the broker asks his followers to participate in political activities and vote (on candidates) on the voting day.In line with, Daniel Bumke (in Irawan,2014) states that vote broker represents candidates or political party as vote buying, which exchange ballot with goods, services or money. Refers to political campaign team as suggests by [2], vote broker duties is equal to Field Operative (field op) which is responsible for finding volunteers and turning them out to canvass, put up and take down lawn signs, and populate phone banks.

Vote brokers are close to voters in the constituency because they interact; observe behavior to learn about voters' tendencies and preferences. Because of this closeness to voters, candidates on the other hand feel dependent on local vote brokers. Brokers or votes brokers have various terms in each region, such as Planet in the area of South Sumatra, Gapit in the Demak area (Tawakkal, 2017) or Dolop in the Magelang area [3]. Vote brokers work not only for legislative candidates, Provincial DPRD, Regency/City DPRD, but also for regional head elections from the Governor, Regent/Mayor level to the Village Head level.

Vote brokers are not part of a success team or winning team that carries one of the candidates in the legislative and regional head election. Therefore, the name of the vote broker is not recorded in the General Election Commission's record. Candidates who are experienced in the political world can usually differentiate between trusted brokers and those who aren't. Conversely, vote brokers are easier to persuade beginner candidates who lack confidence. Vote brokers do not only act as couriers who deliver campaign props (flyers and leaflets) from candidates to prospective voters. The vote brokers play an interactive communication role to make voters more open to receiving information about certain candidates who are mediated by the 'Vote Broker'. On the other hand, with the existence of vote brokers, the candidates can more 'understand' the wishes of each group of prospective voters in a more concrete manner.

This article will discuss the types and activities carried out by vote brokers as intermediaries for candidates with voters in the period leading up to the general election. Data was obtained through in-depth interviews with journalists, academics and a number of candidates who competed in the 2019 Legislative Election in Bengkulu Province. The purpose of this paper is 
to understand the relationship between candidate-broker-voters in general elections. With the understanding of tripartite relations, it is expected to contribute to the development of political marketing communication science.

\section{Finding and Discussion}

Based on the results of the study, there are 6 (six) types of relations of tripartite relations between candidates - vote broker - voters obtained through in-depth interviews with various sources.

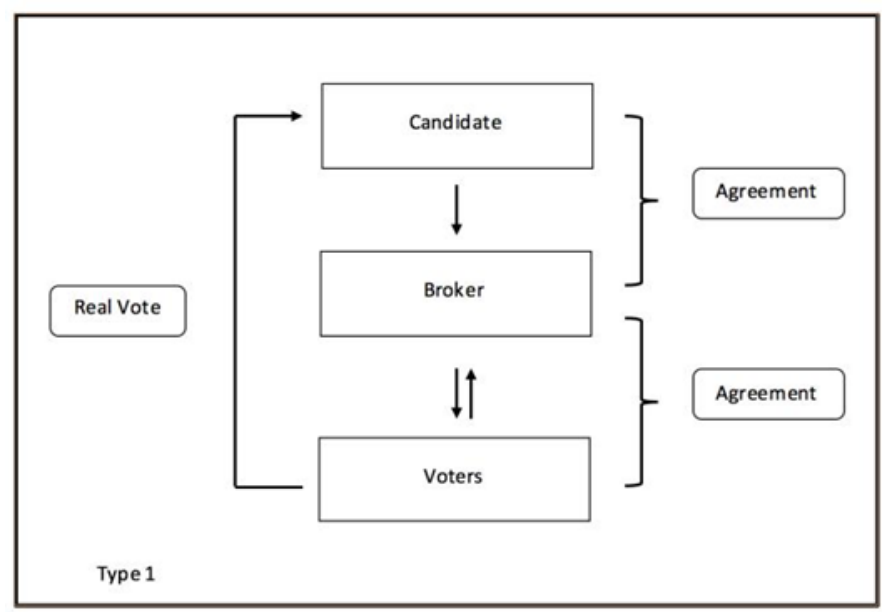

Fig 1. The First type of candidates - vote broker - voters relationship

The relation of candidates - vote brokers - voters type 1 occurs when candidates who take the initiative seek support through nodes that are considered capable of bringing candidates closer to voters. The chosen node is a community leader or group leader both formal and informal. This node is the vote broker or bridge between candidates and voters. Generally, vote brokers have an agreement with voters to cast their votes to candidates if candidates are able to implement the conditions requested by voters through brokers. This form of transaction can be in the form of goods, activities or money. Furthermore, vote brokers carry voters' mandates and negotiate with candidates.

An example of this type 1 relationship is a legislative candidate who asks for help from a community leader (such as the Neighborhood Association (NA) head) to socialize himself to their NA residents and expects the NA residents to vote for the candidate. The head of the NA then became a broker who conveyed the messages and requests of the intended legislators to their citizens. Because of the residents' trust in the NA Chairperson, the NA Residents agreed to vote for the intended Legislative Candidate as long as the Legislative Candidate was willing to build a siring or small canal in their neighborhood. For candidates, this agreement is considered beneficial because candidates can make the results of the agreement brokered by the Chairman of the NA to get his real vote with a certain number of people in the list of specific names and addresses (by name - by address). As a consequence, with this agreement, voters and vote brokers will no longer make agreements with other candidates for the contestation of legislative elections at the same level. Based on research findings, vote brokers in type 1 
relations are generally found in new residential or environmental areas with people who are usually young with a multi-cultural background.

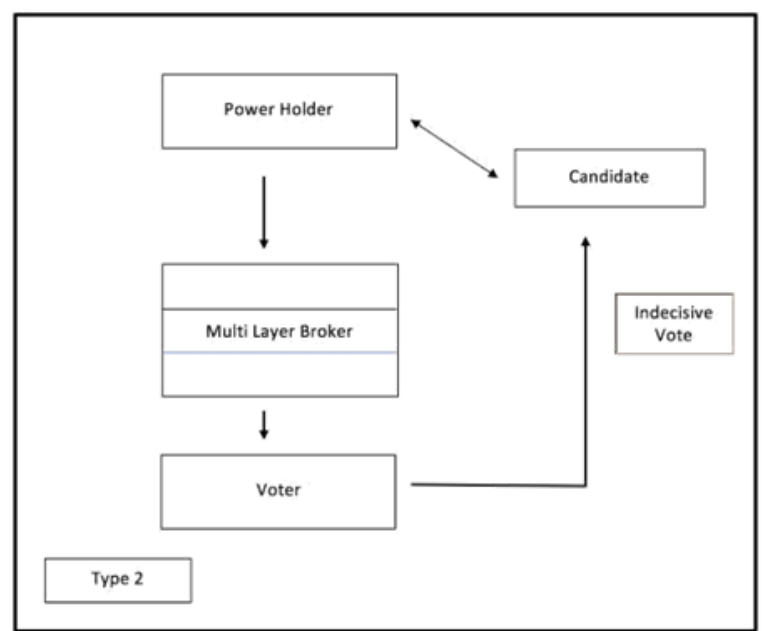

Fig 2. The second type of candidates - broker - voters relationship

Different from type 1, in relation to candidate- vote broker-voter 2 because it is not directly related between candidates and brokers and voters. In some cases, candidates do not make personal contact with vote brokers. Broker/transactional connected broker. Power holders with their authority move brokers with tiered structures to support voters. The next broker is to divert voters from the electoral district where (the) candidates compete. All forms in the form of material and immaterial needed in the process of persuasion are the responsibility of the broker.

Brokers 2 were found in the legislative elections in Bengkulu Province where the holders of power in this case the head of the region or head of the agency, moved people who were structurally related under his authority to get certain candidates. One subordinate was targeted for 20 votes. Although the number of subordinates needed is more than that, but the votes promised cannot be categorized as real votes because voters may not vote for the candidates requested by brokers.



Fig 3. The third type of candidates - vote broker - voters relationship 
The active and aggressive role of vote brokers is very visible in the relation of candidate-brokervoters type 3. If other types of brokers only work after the candidate's name appears in the Permanent Candidate List (PCL), the type 3 broker instead initiates and encourages the entry of candidates in contestation. First brokers approach people who are considered potential. Brokers see the attractiveness of targets in terms of capability and capacity. Those people who are targeted are considered to have social capital (popularity and character) and financial capital (costs to compete). To the target, the vote broker promises to find supporters in the electoral district who will become a battleground. If the target is included in the PCL, vote brokers start working on voters by making meetings between candidates with voters, or simply providing information on the whereabouts of candidates. The votes promised by vote brokers to candidates also cannot be predicted because voters are unpredictable. These type 3 brokers are from political parties, academics and political practitioners.

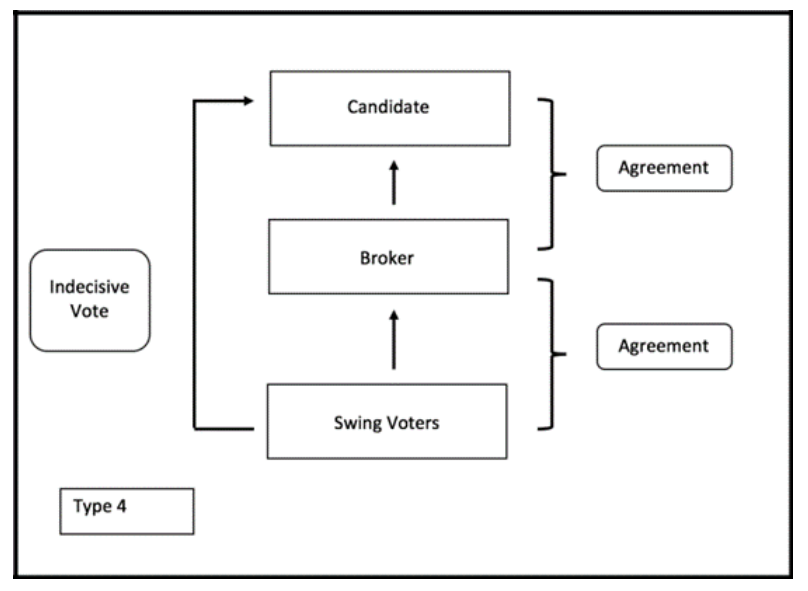

Fig 5. The fifth type of candidates - vote broker - voters relationship

Type 5 brokers are unique because voters are imaginary. Brokers do not promise themselves to come to provide information and persuade voters as other types of brokers do. In contrast, brokers only deal with candidates. Type 5 brokers appear in paranormal, shaman, 'smart' people or those who have supranatural abilities. Brokers promise to help candidates win by opening the aura to make them look most prominent among all election contestants, and to close the views of other voters. For that, candidates need to do a ritual guided by the broker who is also a psychic. The broker's requested rituals include a midnight bath with flower potions to slaughter a goat with certain characteristics. Considering the character of voters is imaginary, the reward of votes promised to candidates is also considered unpredictable. 


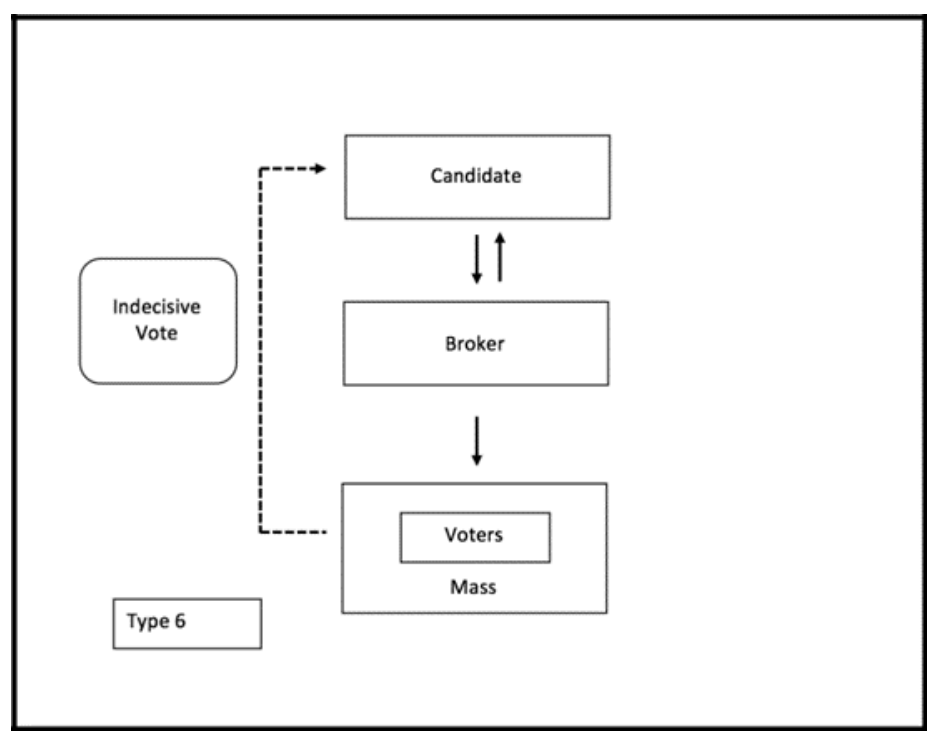

Fig 6. The sixth type of candidates - vote broker - voters relationship

The relation between candidates and voters in type 6 is mediated by brokers who act as a kind of event organizer for candidates. In its emergence, this type of vote broker does not promise votes but seeks to bring candidates closer to the masses through creating major events. Type 6 brokers are generally still relatively young and move in urban areas. In line with the age of the vote broker, the events offered tend to be aimed at teenagers or beginner voters, such as futsal competitions or sports to famous music group concerts. Because brokers do not promise a certain amount of votes, then the vote nature obtained by candidates is also unpredictable.

Based on the recognition of the legislative candidates who were used as informants, they were more able to believe in the vote choice validity and the certainty of the commitments they made with prospective voters brokered by brokers through the tripartite communication type 1, type 2 , type 3 , type 4 , and type 5 . Whereas in the type 6 communication relations system it is considered that it cannot be believed that it will contribute to the clear vote results. Through relations and communication as well as commitments that occur through the role of brokers in types 1 to 5, a legislative candidate can predict the vote acquisition more clearly and measurably. After completing the prediction of the vote acquisition with a certain percentage deviation, a legislative candidate can then find out how much more he has to make an agreement in order to excel in competition with other fellow legislative candidates, both from fellow and other parties.

In connection with the facts of the five types mentioned above, it can be formulated an understanding that brokers in tripartite communication systems of type 1 to type 5 have acted as Vote Engine creators for legislative candidates. 


\section{Conclusion}

Based on the results of the discussion, it can be concluded that:

1. Legislative elections with an open candidate list system and the most votes held in Indonesia especially in 2019 lead to the emergence of a type of tripartite relationship between candidates (legislative candidates) - brokers - voters.

2. For a legislative candidate who contests in the 2019 legislative elections, tripartite relations system type 1 , type 2 , type 3 , type 4 , and type 5 are more believed to be able to provide clearer, more predictable and measurable vote results.

3. Brokers in tripartite communication relations system type 1 , type 2 , type 3 , type 4 and type 5 are vote engines for legislative candidates who employ them.

\section{References}

[1] S. C. Stokes, T. Dunning, M. Nazareno, and V. Brusco, Cambridge studies in comparative politics: Brokers, voters, and clientelism: The puzzle of distributive politics: The puzzle of distributive politics. Cambridge, England: Cambridge University Press, 2014.

[2] C. Shaw, The campaign manager: Running and winning local elections, 4th ed. Westview Press, 2009.

[3] "Hati-hati, Makelar Politik Mulai Beraksi - suaramerdeka.com.” [Online]. Available: https://www.suaramerdeka.com/smcetak/baca/144649/hati-hati-makelar-politik-mulaiberaksi. 